The

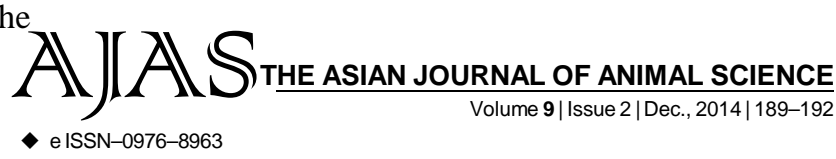

DOI : 10.15740/HAS/TAJAS/9.2/189-192 Visit us | www.researchjournal.co.in $\mathrm{S}$

RESEARCH ARTICLE.........

\title{
Textural quality profile of goat milk fortified Paneer
}

\author{
A.L. SUPEKAR, S.G. NARWADE, R.P. KADAM AND SYED IMRAN HASHMI
}

Author for Corresponding -

\section{S.G. NARWADE}

Department of Animal Husbandry

and Dairy Science, College of

Agriculture, Vasantrao Naik

Marathwada Krishi Vidyapeeth,

PARBHANI (M.S.) INDIA

Email: narwades@ rediffmail.com

See end of the article for Coopted authors'
ABSTRACT...... The present study was carried out to assess the textural quality profile of goat milk fortified Paneer. Paneer was prepared using buffalo milk with different proportions of goat milk (viz., 25, 50 and 75\%) and prepared Paneer was subjected to the textural analysis on TA-XT texture analyzer. On the basis on resulting graph, various textural characteristics like hardness, cohesiveness, adhesiveness, springiness and chewiness were determined. The overall textural profile of Paneer showed that sample $\mathrm{T}_{1}$ was superior in terms of overall textural profile compared to that of $\mathrm{T}_{0}$ (control), $\mathrm{T}_{2}$ and $\mathrm{T}_{3}$ treatments. The incorporation of goat milk in the buffalo milk up to 25 per cent forms a good textural structure of the Paneer.

KEY WORDS...... Paneer, Goat milk incorporation, TA-XT texture analyzer, Textural profile

HOW TO CITE THIS ARTICLE - Supekar, A.L., Narwade, S.G., Kadam, R.P. and Hashmi, Syed Imran (2014). Textural quality profile of goat milk fortified Paneer. Asian J. Animal Sci., 9(2) : 189-192.

ARTICLE CHRONICLE - Received : 14.10.2015; Revised : 14.11.2014; Accepted : 28.11.2014 